\title{
Luzias e Saquaremas em confronto: A organização judiciária como problema político no Brasil imperial
}

\author{
Ricardo Freitas ${ }^{1}$
}

\begin{abstract}
Resumo
Embora frequentemente os juristas tendam a superestimar o conteúdo técnico da legislação em detrimento de seu aspecto político, parece claro que ambos encontram-se intimamente conectados. Este texto pretende demonstrar com apoio no exame da legislação imperial em matéria de organização judiciária como se operou, em termos concretos, a influência da superestrutura política imperial sobre a matéria jurídica. No curso do período imperial de nossa história, tendências políticas mais acentuadamente liberais ou conservadoras preocupadas, respectivamente, com a organização política do Estado imperial, com o conflito de interesses entre Governo Imperial e Províncias e com o conteúdo e extensão dos direitos e garantias individuais, digladiaram-se em torno da legislação em matéria de organização judiciária visando conformá-la aos seus desígnios, numa evidente demonstração da interdependência entre as esferas da política e do direito.
\end{abstract}

Palavras-chave: Estado Imperial; Organização Judiciária; Federalismo; Liberalismo.

Confrontación entre "Luzias" (liberales) y "Saquaremas" (conservadores): La organización judicial como problema político en el Brasil imperial

\section{Resumen}

Este texto pretende demostrar, a partir del análisis de la legislación imperial en materia de organización judicial, cómo se operó la influencia de la superestructura política imperial sobre la justicia. Durante el curso de vigencia del imperio brasileño, tendencias políticas más claramente liberales o conservadoras, preocupadas por la organización política del Estado Imperial, por el conflicto de intereses entre el gobierno imperial y la provincias y por el contenido y la extensión de los derechos y garantías individuales, se batían por la legislación relativa a la organización judicial, buscando conformarla a sus propósitos, en una clara demostración de la interdependencia entre las esferas de la política y del derecho.

Palabras clave: Estado Imperial; organización judicial; federalismo; liberalismo.

\footnotetext{
1 Professor de História do Direito Penal no Doutorado em Direito da Universidade Federal de Pernambuco, Professor de Direito Penal na Faculdade de Direito da Universidade Federal de Pernambuco, Professor de Direito Penal da Faculdade Damas da Instrução Cristã, Procurador da Justiça Militar. E-mail: ricardo.freitas@mpm.mp.br
} 
The clash between the Luzia (liberals) and the Saquarema (conservative) parties: court structure as a political problem in the Empire of Brazil

\section{Abstract}

This text aims to demonstrate the influence exerted by the imperial political superstructure on legal affairs, by examining imperial legislation on court structure. Throughout the existence of the Empire of Brazil, the more liberal or conservative political voices fought over legislation on court structure, concerned as they were by the political organization of the imperial state, the conflict of interests between the imperial government and the provinces and the content and extension of individual rights and guarantees. Their aim was to make the legislation conform to their designs, in a clear demonstration of the interdependency between the political and the legal spheres.

Keywords: Imperial state; court structure; federalism; liberalism.

Luzias (libéraux) et Saquaremas (conservateurs) en conflit: le problème politique de l'organisation judiciaire dans le Brésil impérial

Résumé

Ce texte entend démontrer, en s'appuyant sur l'examen de la législation impériale en matière d'organisation judiciaire, de quelle manière opéra l'influence de la superstructure politique impériale sur la Justice. Tout au long de l'Empire brésilien, des tendances politiques, des plus libérales aux plus conservatrices, soucieuses de l'organisation politique de l'État impérial, du conflit d'intérêt entre le gouvernement impérial et les provinces, et du contenu et de l'extension des droits et des garanties individuelles, se sont affrontées autour de la législation en matière d'organisation judiciaire, et ce dans le but de la conformer à leurs desseins, en une évidente démonstration de l'interdépendance entre les sphères de la politique et du droit.

Mots-clés : État impérial ; organisation judiciaire ; fédéralisme ; libéralisme.

\section{自由党人和保守党人的冲突：巴西帝国时代的作为政治问题的司法组织}

摘要:

本文分析了巴西帝国时代司法组织, 帝国政治结构对司法组织的影响。在整个帝国时代 1889), 政治上有两个派系, 一是自由派, 二是保守派, 在政治组织, 帝国中央和各个行省之间的利益冲突 方面,

各自拥有自己的主张, 对个人权力定义, 和权利的保障等法制方面的问题, 俩派相互冲突。它们对司法组 织有不同的诉求，都希望司法部门听从自己一方的主张。这特出反映出政治和法律的相互依靠的关系。 关键词：帝国政府，司法组织，联邦主义，自由主义。

\section{A Organização Judiciária como Problema Político no Brasil Imperial}

No período colonial de nosso passado talvez fosse mais acertado falarmos em "Brasis", no plural, que no "Brasil", no singular. De fato, a considerável extensão territorial, aliada à significativa dispersão populacional favoreceram a emergência de uma pluralidade de organismos administrativos e judiciais autônomos ou 
semiautônomos subordinados exclusivamente à metrópole e na maioria dos casos em termos meramente formais. ${ }^{2}$ Tal realidade, por sinal, não se modificou sequer com a extinção do sistema de capitanias hereditárias e com a criação do governo geral. Somente com o advento da independência o referido quadro começou a se transformar lentamente a partir da adoção de medidas políticas destinadas a assegurar a centralização política e administrativa do novel Estado imperial.

A independência não modificou radicalmente as estruturas socioeconômicas nacionais, limitando-se, o que não deixa de ser importante, a alterar as suas estruturas jurídicas e políticas. Na realidade, a conservação daquelas demandou as mutações legais efetivadas nestas. Quando da independência, um novo pacto intra elites precisou ser forjado a partir da figura do Imperador, o que exigiu, por seu turno, a criação de estruturas jurídicas aptas a amparar politicamente o Estado imperial. Em Estados monárquicos constitucionais, a Lei Maior pretendia refletir o pacto político supostamente destinado à preservação do bem comum e dos direitos de cidadania e não dos interesses exclusivistas desta ou daquela camada social privilegiada. No Brasil pós-independência uma das maiores dificuldades para a realização do mencionado projeto residia precisamente no conteúdo do referido contrato social, particularmente no que concerne à forma de Estado mais adequada no sentido de assegurar o indispensável equilíbrio entre governabilidade/preservação da integridade nacional e conservação das liberdades individuais e políticas. Basicamente, tratava-se de alcançar um equilíbrio entre a estabilidade do próprio regime monárquico e o exercício dos direitos civis e políticos que consubstanciam as liberdades públicas em um Estado constitucional.

Um Estado unitário "clássico" seria politicamente impraticável, considerando-se a forte tradição autonomista das diversas regiões do país. Por conseguinte, alguma autonomia política e administrativa no nível provincial e mesmo municipal mostrava-se indispensável. Porém, a grande dificuldade com a qual se deparava o legislador residia na fixação do grau de autonomia a ser estabelecido na Constituição do Império e, posteriormente, na legislação infraconstitucional. Tal dificuldade, por outro lado, era exacerbada pela feição peculiar do nosso liberalismo. O liberalismo político brasileiro

\footnotetext{
${ }^{2}$ Cf. Prado Júnior, Caio (1999). Evolução Política do Brasil, São Paulo: Brasiliense, p.32.
} 
era impregnado de espírito regionalista. O liberal autêntico ou radical era também um defensor da tese da máxima descentralização do poder político. Para significativa parcela dos liberais brasileiros, a comunidade local era mais importante que a Província e, esta, bem mais importante que o próprio Império. Mas também é importante registrar que, em sua maioria, quase todos os políticos brasileiros no período acreditavam ser a forma monárquica do governo a mais adequada, sendo os republicanos bastante minoritários na cena política. Além disso, quase todos professavam em variados graus o liberalismo, ideário considerado como sendo aquele mais compatível com a missão civilizatória por eles assumida.

O panorama do nascente Império revela a existência de três correntes políticas que se digladiavam em torno da forma de Estado a ser adotada. Havia os defensores de um nível elevado de centralização política e administrativa, ou seja, de uma espécie de Estado unitário com poderes desconcentrados somente o suficiente para animar minimamente a vida provincial de modo a não colocar em risco a unidade política do Império. Também existiam aqueles que propunham a federalização do Estado em moldes semelhantes aos Estados Unidos com a finalidade principal de proteger os interesses particulares das diversas Províncias - sobretudo aquelas localizadas na periferia do Império - contra as ambições que consideravam despóticas do Governo Central. Ademais, consideravam que o federalismo contribuiria para tutelar com maior eficiência os direitos civis e políticos contra o autoritarismo. Por último, outros defendiam, também em nome do federalismo, conceito ainda em formulação na época, a ideia de que o Brasil devia organizar-se numa espécie de confederação de Estados, o que, naturalmente, implicaria não na autonomia provincial propriamente dita, mas na independência e transformação das Províncias em verdadeiros Estados. Em contrapartida, na opinião dos adeptos da centralização política e administrativa a federalização, independentemente do grau de autonomia concedido aos entes políticos locais, provocaria a fragmentação do Estado de maneira semelhante ao ocorrido na América espanhola em razão dos choques dos interesses conflitantes das Províncias. Para estes, a única maneira de evitá-lo seria mediante a manutenção de um governo central suficientemente forte capaz de harmonizá-los em torno do bem comum. No entendimento dos defensores do federalismo, pelo contrário, o progresso geral do país 
dependeria da defesa feita pelas Províncias de seus interesses particulares a despeito da vontade do poder central. A competição entre todas elas de alguma maneira resultaria, ao final, no melhor para cada uma. ${ }^{3} \mathrm{~A}$ disputa em torno da organização judiciária do Brasil imperial resultou num exacerbado confronto político que, no longo prazo, culminou com a vitória da facção mais próxima do ideal centralizador.

O exame da organização judiciária brasileira no período imperial demonstra de maneira inequívoca a relação existente entre a produção das normas jurídicas - no presente caso, das normas jurídicas destinadas à organização do aparato repressivo e a estrutura política da sociedade. O presente texto pretende justamente contribuir para explicitar a relação entre direito e política a partir do exame de um dos períodos mais importantes de nosso passado.

\section{Código do Processo de 1aㅡ Instância (Lei de 29 de novembro de 1832): Hegemonia Liberal e Descentralização Política}

Em decorrência de sua natureza nitidamente centralizadora, a Constituição Imperial de 1824 não foi aceita com entusiasmo pelos liberais, haja vista que estes defendiam a concessão de uma maior autonomia às Províncias. Contudo, a reforma constitucional não era tarefa das mais simples, razão pela qual os partidários da descentralização optaram por transformar o panorama vigente através de reformas na legislação infraconstitucional. A primeira delas, datada de 1831, pretendendo reforçar o Poder local, consistiu na criação da Guarda Nacional, milícia comandada pelos grandes proprietários rurais. A segunda, de inspiração igualmente liberal e descentralizadora, efetivou-se com a entrada em vigor do Código do Processo de 1aㅡ Instância em 1832.

O Código do Processo de $1^{\underline{a}}$ Instância e o Código Criminal do Império (1830) nada mais foram que o produto de um esforço dirigido à construção do Estado brasileiro a partir de matrizes liberais com a finalidade de conduzir o Brasil à modernidade nos mesmos moldes que os países europeus. No período imediatamente posterior à independência, tanto liberais como conservadores concebiam o direito

\footnotetext{
${ }^{3}$ Cf. Coser, Ivo (2008). Visconde do Uruguai: Centralização e Federalismo no Brasil (1823-1866), Belo Horizonte: UFMG, p.256.
} 
penal, o direito processual penal e a organização judiciária e policial até então vigentes como resquícios de um passado colonial deslustrado, obscurantista e opressor. Por tal razão, todas as correntes políticas nacionais insistiam em reformas legislativas que, em seu entendimento, propiciariam, ao final e ao cabo, o ingresso do país na modernidade. ${ }^{4}$ Tratava-se de negar a herança legislativa colonial portuguesa de natureza absolutista, o que, de fato, foi parcialmente conseguido pelo legislador brasileiro.

Em 1831, isto é, no intervalo entre a promulgação do Código Criminal do Império e o Código do Processo de $1^{\underline{a}}$ Instância, o primeiro Imperador do Brasil, não conseguindo superar a crise política, abdicou em favor de seu filho, menor de cinco anos de idade. Percebendo as possibilidades propiciadas pela abdicação, as forças liberais esforçaram-se para empreender a reorganização do Estado na direção da descentralização política da qual o Código do Processo foi uma das expressões mais importantes.

No Código do Processo de $1^{\text {a }}$ Instância (doravante apenas Código) encontravam-se não apenas as normas processuais penais reguladoras dos processos penais, mas ainda o conjunto das regras referentes a toda organização judiciária imperial. Afastando-se do espírito da Constituição Imperial e do próprio Código Criminal do Império, de espírito liberal moderado, o Código acolheu teses liberais radicais em detrimento das tendências liberais mais conservadoras então hegemônicas. Ele fortaleceu as autoridades judiciárias locais em detrimento do Governo Central. Na realidade, o Código pode ser considerado a máxima expressão do espírito descentralizador e liberal autêntico no período imperial, visto que não se limitou a transferir poderes do Governo Central às Províncias, mas foi muito além ao estabelecer o Município como base da organização judiciária nacional.

Dentre os aspectos mais propriamente liberais do Código destacavam-se o direito de defesa (razoavelmente amplo), a previsão da fiança, a proibição da prisão sem ordem judicial, o duplo grau de jurisdição e a exigência de mandado judicial para a realização de buscas e apreensões. Também se faz merecedora de registro a transferência de amplas atribuições policiais e judiciais ao Juiz de Paz, o que alterou

\footnotetext{
${ }^{4}$ Cf. Holloway, Thomas H (1997). Polícia no Rio de Janeiro: Repressão e Resistência numa Cidade do Século XIX, Rio de Janeiro: Fundação Getúlio Vargas, p.45-46.
} 
substancialmente a estrutura do aparelho policial herdado cuja feição provinha das últimas décadas do período colonial.

A polícia surgiu quando da transferência da família real para o Brasil em 1808. Naquela oportunidade foi criada a Intendência Geral de Polícia da Corte e do Estado do Brasil em 10 de maio de 1808. Tratava-se de uma instituição inspirada no modelo francês de polícia adotado em 1760 por Portugal. Dentre as amplas atribuições policiais destacavam-se a supervisão de obras públicas, incluindo as de iluminação pública, de abastecimento da cidade e de manutenção da ordem pública. O intendente, chefe da polícia, era nomeado dentre os desembargadores e tinha status de ministro de Estado.

A hegemonia do Poder Local em matéria policial e judicial foi assegurada pelo Código, que atribuiu uma série de competências tanto ao Juiz de Paz como ao Júri em detrimento da Chefia de Polícia e dos demais órgãos do Poder Judiciário. Na realidade, o Juizado de Paz, criado em 1827, vale dizer, cinco anos antes do Código, assumiu completamente as atribuições do Delegado de Polícia, cargo extinto por disposição legal expressa (artigo 19). O significado de tal alteração legislativa não poderia ser mais claro: consistia em pôr sob a presidência de uma autoridade local, mais precisamente de uma autoridade eleita pela comunidade, sem qualquer vínculo com o governo central, o poder de prender e de julgar. O Juiz de Paz tinha competência para expedir mandados de prisão, mandados de busca e apreensão, conceder fiança, formar a culpa, participar da confecção da lista dos integrantes do Júri, julgar crimes de menor gravidade, enfim, de disciplinar e controlar o comportamento da população no Distrito de Paz onde atuava.

Ao tratar da organização judiciária, o Código determinou em seu artigo 1ํㅜ que nas Províncias os Juízos de primeira instância se subdividiriam em Distritos de Paz, Termos (Julgados) e Comarcas. Nos Distritos de Paz, a prestação jurisdicional era realizada de maneira mais próxima da população, influenciando mais diretamente seu cotidiano.

O Código determinava a existência de um Juiz de Paz para cada Distrito de Paz (artigo 4ํㅜ). Na realidade, no nível do Distrito de Paz o Juiz de Paz era a única autoridade judicial. Ele era escolhido por nomeação dentre quatro cidadãos ativos eleitos para o cargo de acordo com a legislação eleitoral então em vigor. Os quatro 
eleitos se sucediam, sendo que o mais votado deles era o primeiro a servir por um ano e assim sucessivamente (artigo 9o e artigo 10). A reeleição era possível, mas o escolhido não era obrigado a servir caso esta tivesse ocorrido no triênio imediatamente posterior ao ano em que ele havia servido (artigo 11). O Juiz de Paz era um órgão do Poder Local, não sendo escolhido nem pelo Imperador nem por qualquer governante ou autoridade judiciária provincial.

Ocupar o cargo de Juiz de Paz era uma obrigação do cidadão eleito para atuar em benefício da comunidade. Ele não era remunerado pelos seus serviços, recebendo tão somente uma quantia em dinheiro a título de emolumentos decorrente dos atos por ele praticados (artigo 49). Em geral, o Juiz de Paz não era pessoa de origem social elevada nem tampouco de condição econômica privilegiada, mas alguém que, proveniente dos estratos intermediários da população, desfrutava de certo prestígio na comunidade. ${ }^{5}$ No esquema liberal e federalista, o Juiz de Paz seria a própria encarnação do poder local, da comunidade política gerenciando sua existência e dirigindo seus próprios destinos.

A competência do Juiz de Paz era amplíssima, sendo algumas eminentemente policiais (artigo 12, $\S \S 1^{\circ}, 2^{\circ}$ e $3^{\circ}$ ) e outras judiciais (artigo $12, \S \S 4^{\circ}, 5^{\circ}$, 6ำ e $7^{\circ}$ ). Nos termos do artigo 12, do Código, o Juiz de Paz tomava conhecimento das pessoas, desconhecidas ou suspeitas, que viessem a morar no Distrito de Paz, podendo conceder-Ihes ou denegar-Ihes passaporte $\left(\S 1^{\circ}\right)$; ele também forçava os "vadios, mendigos, bêbados habituais, prostitutas que perturbam o sossego público e os turbulentos que por palavras ou ações ofendem os bons costumes a paz das vítimas e a tranquilidade pública a assinarem termo de segurança" $\left(\S 2^{\circ}\right)$; ele obrigava ainda os suspeitos que desejassem cometer crimes a assinar termo de segurança ( $\left(3^{\circ}\right)$; formava a culpa dos delinquentes e providenciava auto de corpo de delito ( $\S 44^{\circ}$ ); prendia os culpados em qualquer Juízo ( $\left(5^{\circ}\right)$; concedia fiança aos que condenava ( $\S$ 6ํ) e, por fim, julgava as contravenções às posturas das Câmaras Municipais, os crimes cuja pena não fosse superior à multa de 100.000 réis, prisão, degredo ou desterro não superior a seis meses (com multa correspondente à metade deste tempo ou sem ela) e casa de correição ou trabalho compulsório em oficinas públicas cuja

\footnotetext{
${ }^{5}$ Cf. Reis, João José; Silva, Eduardo (1989). Negociação e Conflito: a Resistência Negra no Brasil Escravista, São Paulo: Companhia das Letras, p.34.
} 
pena não fosse superior a três meses $\left(\S 7^{\circ}\right)$. As sentenças proferidas pelo Juiz de Paz podiam ser objeto de recurso às Juntas de Paz, instância recursal em nível municipal composta por cinco (no mínimo) ou por dez (no máximo) Juízes de Paz (artigos 213 e 216).

No pensamento liberal autêntico, a existência do Juiz de Paz pretendia assegurar a transparência das decisões judiciais, contrapondo-se assim ao segredo característico do processo penal marcadamente inquisitivo das monarquias absolutistas. De acordo com o pensamento liberal, o Estado tinha o dever de garantir a publicidade dos julgados para que todos os cidadãos pudessem ter conhecimento integral a seu respeito. Contudo, além disso, o Juiz de Paz pretendia que o cidadão tomasse as rédeas de seu próprio destino, inclusive no que diz respeito à administração da justiça, afastando assim a presença incômoda e invasiva do Governo Central, tido pelos liberais como potencial inimigo das liberdades públicas. Neste aspecto, até mesmo os liberais mais moderados defendiam a tese de que o Juiz de Paz era peça chave da descentralização política. Diferentemente dos liberais autênticos, porém, eles tinham plena consciência de que, em última análise, os Juízes de Paz, embora eleitos dentre os cidadãos politicamente ativos, não podiam deixar de estar sob a influência da elite política e econômica local. ${ }^{6}$ De toda sorte, o fato é que a ampla competência dos Juízes de Paz traduziu "o fortalecimento das autoridades locais e regionais" em virtude da influência política exercida naquele momento pelas correntes liberais na condução dos destinos da nação. ${ }^{7}$ Há quem diga que a criação do cargo de Juiz de Paz (1827), mesmo sem que este desfrutasse da extensa competência que lhe foi atribuída em 1832 pelo Código, revestiu-se de tamanha importância que marca verdadeiramente o início da "década liberal" do passado imperial brasileiro. ${ }^{8}$ Mas também não podemos esquecer a existência de outro órgão do Poder Judiciário imperial dotado de características eminentemente liberais: o Júri.

Nos Termos (Julgados), o Judiciário era integrado pelo Conselho de Jurados (Jurados), pelo Juiz Municipal e pelo Promotor Público (artigo 5ํํ). Destes órgãos, o

\footnotetext{
${ }^{6}$ Cf. Coser, Ivo (2008). Op. Cit., p.74-77.

${ }^{7}$ Neves, Lúcia Maria Bastos Pereira das; Machado, Humberto Fernandes (1999). O Império do Brasil, Rio de Janeiro: Nova Fronteira, p.126-127.

${ }^{8}$ Cf. Flory, Thomas (1986). El Juez y el Jurado en el Brasil Imperial, 1808 -1871: Control Social y Estabilidad Política en el Nuevo Estado, México: Fondo de Cultura Económica, p.22.
} 
Conselho de Jurados era, sem dúvida, o mais importante. Os Jurados eram escolhidos, assim como o Juiz de Paz, dentre os cidadãos ativos de reconhecido bom senso e probidade (artigo 23) a partir de uma lista confeccionada em cada um dos Distritos. $\mathrm{Na}$ verdade, havia dois Conselhos de Jurados: o denominado $1^{\circ}$ Conselho de Jurados ou Júri de Acusação, competente para decidir preliminarmente se existia ou não "matéria de acusação" contra alguém, isto é, se o acusado devia ou não ser pronunciado; e o chamado $2^{\circ}$ Conselho de Jurados ou Júri de Sentença, órgão que julgava o mérito para condenar o absolver o réu nos crimes excluídos da competência do Juiz de Paz, vale dizer, nos crimes de média ou grande gravidade. O Júri de Sentença era composto por doze jurados que decidiam por maioria de votos.

Jamais o Júri voltou a ter, no Brasil, a importância que Ihe foi conferida pelo Código de 1832. A notável extensão da sua competência não expressava uma opção técnica, mas uma decisão política do legislador. Ele acreditava que o Júri pudesse assegurar melhor as liberdades civis que o Juiz singular. Ao menos em tese, doze julgadores estariam mais protegidos contra as pressões políticas que um magistrado isolado. Ademais, o legislador supunha que a justiça dos julgamentos dependia muito mais da experiência de vida, do conhecimento dos costumes então em vigor, enfim, do saber cotidiano, que da sapiência jurídica, do saber puramente técnico-jurídico. Por fim, o legislador pensava que o réu seria julgado com maior grau de imparcialidade se o fosse por seus iguais, pessoas comuns de sua própria comunidade. ${ }^{9}$ Além disso, não deixa de ser significativo o fato de que o Júri, consagrado pelo Código como principal órgão do Poder Judiciário, tenha sido incorporado dois anos antes (1830) ao ordenamento jurídico nacional exatamente no curso do conflito entre o Imperador e parte significativa da elite imperial. A tese de que a segurança jurídica dependeria da existência de órgãos jurisdicionais formados por Juízes eleitos e não por Juízes nomeados pelo governo central ou provincial expressou tanto o ponto de vista dos liberais mais radicais quanto dos moderados em detrimento da posição defendida pelos segmentos políticos mais conservadores.

\footnotetext{
${ }^{9}$ Slemian, Andrea (2008). "A nação independente, um novo ordenamento jurídico: a criação dos Códigos Criminal e do Processo Penal na primeira década do Império do Brasil”. In Ribeiro, Gladys Sabina (Org.) (2008). Brasileiros e Cidadãos: modernidade política, São Paulo: Alameda, p.201-202.
} 
Transcorridos poucos anos de vigência do Código, certas forças políticas começaram a atuar visando à redução do poder das comunidades locais e o alargamento dos poderes provinciais e centrais, tendo obtido êxito na empreitada.

\section{O Ato Adicional (Lei no 16, de 12 de agosto de 1834): Rumo à Centralização Política}

O Ato Adicional consistiu numa reforma constitucional de tendência política federalista liderada pela corrente liberal de inspiração moderada em conjunto com as forças mais conservadoras (ambas integrantes do núcleo da elite imperial) em desfavor dos interesses defendidos pelos liberais autênticos ou radicais.

Para alguns estudiosos, o significado da reforma consistiu no abandono por parte dos liberais moderados da pretensão de representarem os interesses dos setores subalternos da sociedade imperial e na adoção de uma perspectiva reformista mais conservadora. Na visão dos liberais moderados, preocupados que estavam com a eclosão de revoltas como as que sacudiram o período regencial, o Ato Adicional seria uma medida indispensável à preservação da unidade nacional. Em seu entendimento, porém, a repressão das ações sediciosas não seria efetivada diretamente pelo Governo Central, mas pelas Províncias. Em suma, a reforma ainda traduzia o compromisso liberal com a descentralização política do Império. ${ }^{10}$ Reconhecendo que a descentralização teria ido mais longe do que deveria os liberais moderados deram uma guinada na direção da centralização, mas sem sacrificar o espírito federalista que ainda os animava.

O Ato Adicional esvaziou o poder das comunidades locais ao conceder às Assembleias Legislativas Provinciais a competência para organizar o Poder Judiciário. Curiosamente, no entanto, o Ato Adicional, considerado por muitos como sendo a maior expressão do federalismo no Brasil imperial, terminou por contribuir, paradoxalmente, no médio prazo, para a centralização política do Império. Ao abrir caminho para o denominado "regresso conservador", a reforma política representou "um primeiro passo rumo à centralização que se concretizaria no começo da década de

\footnotetext{
${ }^{10}$ Cf. Coser, Ivo (2008); Op. Cit.; p.100.
} 
1840". ${ }^{11}$ Tal reforma constitucional atingiu não somente a organização judiciária imperial, mas também suprimiu a possibilidade do Poder Moderador ser exercitado durante a Regência, além de extinguir o Conselho de Estado.

No que tange à organização judiciária, as Assembleias Legislativas Provinciais tinham competência para legislar "sobre a polícia e a economia municipal, precedendo proposta das Câmaras" (artigo 10, $\S 4^{\circ}$ ). Além disso, as Assembleias também podiam legislar "sobre a criação e supressão dos empregos municipais e provinciais, e estabelecimento dos seus ordenados". Mas que empregos seriam esses? Numa interpretação autêntica do dispositivo, o próprio Ato Adicional esforçou-se para explicitá-los: "todos os que existirem nos Municípios e Províncias, à exceção dos que dizem respeito à administração, arrecadação e contabilidade da Fazenda Nacional; administração da Guerra e Marinha; e dos Correios Gerais; dos cargos de Presidente da Província, Bispo, Comandante Superior da Guarda Nacional, membros das Relações e Tribunais Superiores, e empregados das Faculdades de Medicina, Cursos Jurídicos e Academias" (artigo 10, $§ 7^{\circ}$ ).

Percebe-se, portanto, que o Ato Adicional transferiu às Províncias o poder de organizar seu sistema policial (em sentido amplo), além de ter-lhes facultado a criação e extinção de cargos judiciais, inclusive mediante a redistribuição das competências dos vários órgãos judiciais então existentes. Valendo-se de tais prerrogativas, diversas Províncias trataram de diminuir o poder das comunidades locais mediante a redução do número de cargos judiciais eletivos e o esvaziamento de suas competências. Em sentido contrário, deu-se o aumento do número de cargos judiciais e da competência dos órgãos judiciais nomeados e supervisionados pelo legislativo provincial. Verificouse, portanto, um deslocamento do poder político das comunidades locais na direção dos Governos Provinciais e não do Governo Central.

De maneira geral, as Províncias limitaram a competência do Juiz de Paz e tornaram igualmente mais restritivas as normas de seleção dos Jurados. Em regra, os poderes do primeiro foram transferidos ao Juiz de Direito, nomeados e supervisionados pelo Poder Provincial. Consequentemente, abandonou-se a possibilidade de eleição dos integrantes da magistratura para os cargos que realmente importavam.

${ }^{11}$ Ferreira, Gabriela Nunes (1999). Centralização e Descentralização no Império: O Debate entre Tavares Bastos e o Visconde de Uruguai, São Paulo: Editora 34, p.30. 
$\mathrm{Na}$ realidade, é preciso reconhecer que argumentos políticos de peso alicerçaram tanto o discurso dos adeptos da reforma quanto o dos que lhe foram contrários. Estes últimos ressaltavam em defesa das amplas competências do Juiz de Paz e do Júri que o preparo técnico do magistrado era menos importante que a sua vinculação à comunidade a qual pertencia. Sua formação jurídica especializada de nada adiantaria caso ele se tornasse um mero funcionário público, subserviente e dócil aos desígnios governamentais, o que colocaria em risco as próprias liberdades públicas. Afinal, de que adiantaria a formação do magistrado sendo ele escolhido, nomeado, sustentado e removível pelos Governos? De resto, afirmavam os liberais radicais, a eleição dos magistrados pela comunidade local asseguraria a escolha dos melhores cidadãos, dos mais capacitados, probos, decentes e imparciais para o exercício da função jurisdicional. Ninguém seria mais imparcial em seus julgamentos que magistrados eleitos que, findo seus mandatos, deixassem a magistratura e voltassem a cuidar de seus próprios negócios, sendo, por seu turno, substituídos por outros integrantes da própria comunidade. Pode-se dizer, dessa maneira, que os liberais autênticos vislumbravam uma organização judiciária assemelhada à inglesa. Em sentido contrário, os adeptos da reforma conferiam ênfase maior ao direito objetivo, ao texto legal, desvalorizando, por outro lado, a experiência de vida, o conhecimento dos problemas da comunidade e a peculiar forma de legitimação do Juiz de Paz. Argumentavam que o Juizado de Paz e o Júri não eram alternativas más em si mesmas, todavia, no estágio organizacional e político no qual o país então se encontrava, muito mais importante seria concentrar esforços na criação de legislação penal e processual penal de qualidade a ser aplicada por funcionários estatais, de acordo com o modelo francês. ${ }^{12}$ Fundamentalmente, porém, subjacente a tais argumentos defendidos pelos liberais moderados, encontrava-se uma profunda desconfiança certamente não destituída de justificativa de que o argumento liberal autêntico ou radical baseado na necessidade de preservação da descentralização máxima do Poder Judicial em nome da excelência do Governo Local agasalhava, na verdade, tendências perigosas que poderiam conduzir à fragmentação política do Estado imperial. Por tal razão, os liberais moderados e conservadores postulavam a

\footnotetext{
${ }^{12}$ Cf. Coser, Ivo (2008). Op. Cit., p.88-99.
} 
reforma do Judiciário com a finalidade de assegurar o que consideravam ser um sadio equilíbrio entre o federalismo - por vezes concebido equivocadamente como defesa da confederação de Estados - e o unitarismo - por vezes confundido com centralismo exacerbado. Em suma, na opinião dos liberais moderados o desafio consistia em assegurar um nível razoável de descentralização política que, por um lado, não comprometesse a unidade nacional e, por outro, não sacrificasse inteiramente a autonomia provincial.

Ao conceder amplos poderes às Assembleias Legislativas Provinciais, o Ato Adicional diminuiu, em contrapartida, a influência política exercida pelos líderes locais, inclusive sobre os órgãos jurisdicionais. Contudo, tal medida acabou por propiciar o surgimento do efeito colateral da disputa entre as Assembleias e os Presidentes de Província, que eram nomeados pelo Governo Central. ${ }^{13}$ Esse novo desafio político resultou na denominada Lei de Interpretação ao Ato Adicional.

\section{A Lei de Interpretação ao Ato Adicional (Lei no 105, de 12 de maio de 1840): A Centralização Política do Império}

Assim como o Ato Adicional (1834), a Lei de Interpretação ao Ato Adicional (1840) foi, de fato, uma verdadeira reforma constitucional, capitaneada desta feita pelas correntes mais conservadoras da política nacional em detrimento das liberais mais autênticas. Significa dizer que todas as veleidades federalistas e, portanto, descentralizadoras, foram conscientemente sacrificadas pelas elites imperiais em favor da centralização política considerada indispensável à conservação da unidade do Estado imperial. Preocupadas com as agitações autonomistas provinciais, as elites nacionais forjaram um duradouro pacto que assegurou a unidade do Estado imperial. Liberais moderados convergiram em suas preocupações com os conservadores, o que resultou na reforma da organização do sistema judiciário imperial.

A Lei de Interpretação ao Ato Adicional assinala o momento do "regresso conservador". Em outras palavras: assinala o instante inicial do processo político que culminou com a hegemonia da corrente conservadora no país. Basicamente, o

\footnotetext{
${ }^{13}$ Cf. Ferreira, Gabriela Nunes (1999). Op. Cit., p.30.
} 
"regresso conservador" pretendia restabelecer a autoridade do Governo Central atingida pela anarquia política que reinou durante a Regência, período de hegemonia liberal. Visava, primeiramente, assegurar a unidade nacional contra seus principais inimigos internos, vale dizer, contra as próprias elites provinciais autonomistas. Ademais, pretendia igualmente reforçá-la para combater os inimigos externos da pátria. ${ }^{14}$ Portanto, politicamente, a Lei de Interpretação ao Ato Adicional representou a conclusão do processo de centralização política do Estado imperial iniciado justamente com o Ato Adicional. Este diminuiu o Poder Local em favor do Poder Provincial, ao passo que aquele esvaziou este último em favor do Poder Central, dando o derradeiro passo para a transformação do Brasil em Estado unitário. Na época, os críticos da reforma constitucional costumavam afirmar, num ataque à centralização política, que em decorrência da Lei de Interpretação ao Ato Adicional o Ministro da Justiça passaria a controlar desde a nomeação do Presidente da Relação à dos carcereiros. ${ }^{15} \mathrm{O}$ fato é que a partir da vigência da Lei de Interpretação, o Governo Central passou a concentrar os poderes dos quais necessitava tanto para submeter às elites provinciais como para combater os inimigos do Império então sediados na bacia do Rio de Prata.

A Lei de Interpretação ao Ato Adicional pretendia superar as dificuldades que teriam sido criadas pelo que seus críticos consideravam ser a excessiva autonomia provincial. Estes sustentavam que a autonomia tinha propiciado às Províncias o poder de alterar como bem quisessem a estrutura judiciária de acordo com seus interesses particularistas, o que teria afetado a unidade do Império enxergada como essencial à preservação dos interesses comuns. Desejando remediar tal problema, a Lei de Interpretação estabelecia que a palavra "municipal" do $\S 4^{\circ}$, do artigo 10 , do Ato Adicional, referindo-se tanto à "polícia" como à "economia", não abrangia a denominada "polícia judiciária", mas tão somente a "polícia municipal" e a "polícia administrativa" (artigo $1^{\circ}$ ). Tal "interpretação autêntica" formulada no artigo $1^{\circ}$, da Lei de Interpretação ao $\S 4^{\circ}$, do artigo 10 , do Ato Adicional, combateu a iniciativa adotada pelas Assembleias Provinciais de recriar, com apoio neste último dispositivo, o cargo de Chefe de Polícia que, recordemos, tinha sido extinto juntamente com o cargo de

\footnotetext{
${ }^{14}$ Cf. Monteiro, Hamilton de Mattos (1990). "Da Independência à Vitória da Ordem". In Linhares, Maria Yedda (Org.) (1990). História do Brasil, Rio de Janeiro: Elsevier, p.140.

${ }^{15}$ Cf. Coser, Ivo (2008). Op. Cit., p. 223.
} 
Delegado por disposição expressa do artigo 19, do Código do Processo de 1a Instância em 1832. De fato, o esvaziamento da competência do Juiz de Paz, por um lado, e o fortalecimento considerado excessivo do Poder Provincial causado pela recriação do Chefe de Polícia e dos Delegados, provocou o efeito colateral indesejado de enfraquecer o Governo Central, o que era considerado inadmissível pelos conservadores. Assim sendo, o remédio prescrito pelo legislador consistiu na reforma da legislação em nome dos interesses nacionais com o abandono do federalismo "de fato" vigente no período de hegemonia liberal que seria ressuscitado apenas com o advento da República. As forças conservadoras acreditavam sinceramente que sem o controle do aparelho repressivo estatal (magistratura, promotoria e polícia) o país estaria sempre sujeito aos rompantes separatistas como aqueles que se verificaram no período regencial. Em sentido contrário, os liberais defendiam firmemente o ponto de vista oposto de que a centralização política, sufocando a autonomia provincial, resultaria numa perda irreparável no que diz respeito à conservação das liberdades públicas.

\section{A Reforma do Código do Processo de 1aㅡ Instância (Lei no 261, de 03 de dezembro de 1841): A Consolidação da Centralização do Estado Imperial}

A reforma do Código do Processo de 1a Instância pela Lei no 261 foi uma consequência inevitável da Lei de Interpretação ao Ato Adicional. Os argumentos favoráveis à reforma eram bastante conhecidos. Afirmava-se que Juízes de Paz e Jurados eram não apenas ineficientes, mas também parciais. Os Juízes de Paz não somente eram destituídos de conhecimentos jurídicos como também não se dedicavam com afinco à jurisdição, pois não eram remunerados e tinham que acumular os afazeres judiciais com seus negócios particulares. Quanto ao Júri, além da influência exercida pelos poderosos locais sobre os Jurados, o órgão tinha dificuldade de se reunir regularmente, o que o tornava uma fonte de impunidade generalizada.

Tendo proibido a criação do cargo de Chefe de Polícia e de Delegado pelos Governos Provinciais, a reforma revogou o artigo 19, do Código do Processo de $1^{\text {a }}$ Instância, vindo a recriar a figura do Chefe de Polícia, mas desta feita subordinando-o 
ao Governo Central. O Chefe de Polícia passou a ser escolhido e nomeado diretamente pelo Imperador ou pelos Presidentes da Província, o que dava no mesmo, na medida em que estes eram igualmente nomeados livremente pelo Monarca. Toda Província, da mesma maneira que a Corte, teria um Chefe de Polícia ao qual se subordinariam Delegados e Subdelegados (artigo $1^{\circ}$ ). Enquanto os Chefes de Polícia eram escolhidos dentre os Desembargadores e os Juízes de Direito, os Delegados os Subdelegados o eram dentre Juízes e cidadãos em geral, sendo obrigatória a aceitação da nomeação por uns e por outros. Chefes de Polícia, Delegados e Subdelegados gozavam da garantia da inamovibilidade (artigo $2^{\circ}$ ), tendo-lhes sido transferidas as competências deferidas pelo Código do Processo de $1^{\text {a }}$ Instância de 1832 aos Juízes de Paz (artigo 4ํㅗ $§ 1^{\circ}$ ). Dentre as suas novas atribuições, merecem destaque o dever de "vigiar e providenciar, na forma das leis, sobre tudo que pertence à prevenção dos delitos e manutenção da segurança ou tranquilidade pública" (artigo $\left.4^{\circ}, \S 4^{\circ}\right)$ e a concessão de fiança aos réus presos ou pronunciados (artigo $4^{\circ}, \S^{\circ}{ }^{\circ}$ ).

Particularmente importante mostrou-se a transferência da formação da culpa do Juiz de Paz para a autoridade policial. Tal atribuição, diga-se de passagem, somente retornou ao Judiciário com a entrada em vigor da Lei nº 2.033, de 20 de setembro de 1871. Por outro lado, o poder atribuído à autoridade policial para julgar crimes de menor gravidade veio a esvaziar o Judiciário, fortalecendo, ao mesmo tempo, um aparelho policial inteiramente subordinado ao Governo Central. Mesmo no que se refere aos delitos de maior gravidade chama a atenção o poder discricionário conferido pela Lei no 261 à autoridade policial, na medida em que facultava ao Delegado de Polícia decidir se o inquérito policial deveria ou não ser enviado às autoridades judiciárias. A referida Lei estabelecia no extenso rol das atribuições das autoridades policiais "remeter, quando julgarem conveniente, todos os dados, provas e esclarecimentos que houverem obtido sobre um delito" (artigo $4^{\circ}, \S 9^{\circ}$ ).

Por sua vez, o Júri tornou-se mais elitizado e restrito, na medida em que a Lei № 261 elevou a exigência de renda para que o cidadão pudesse integrá-lo (de 100.000 réis para 400.000 réis nas quatro principais cidades do Império - Rio de Janeiro, Salvador, Recife e São Luís do Maranhão -; de 300.000 réis nas demais e 200.000 nos Termos), exigindo-se renda em dobro na hipótese dos ganhos serem provenientes do 
comércio e da indústria (artigo 27). Ademais, a lista de Jurados passou a ser confeccionada pelo Delegado de Polícia (artigo 28) que, recordemos, era nomeado pelo Imperador ou pelo Presidente da Província. Além disso, foi extinto o Júri de Acusação (artigo 51).

A Lei no 261 contribuiu para a profissionalização dos magistrados. Juízes de Direito e Juízes Municipais tinham que ser formados em direito (artigo 13 e artigo 22), ao passo que os Promotores deveriam ser escolhidos preferencialmente dentre os bacharéis. Tanto os Juízes como os Promotores eram nomeados e demitidos livremente pelo Imperador, não existindo a garantia da vitaliciedade. Na verdade, Juízes e Promotores serviam por apenas quatro anos, sendo permitida a sua recondução por mais quatro (artigo 14). Os Promotores, podendo ser leigos, podiam ser nomeados interinamente pelo Juiz de Direito (artigo 22). Por seu turno, os Juízes de Direito eram escolhidos dentre os bacharéis que tivessem servido com distinção como Juiz Municipal, Juiz de Órfão ou Promotor Público pelo período mínimo e continuado de quatro anos (artigo 24). Em suma, a Lei no 261 permitiu o controle do Imperador sobre a magistratura e a polícia, ao mesmo tempo em que aprofundou o esvaziamento dos poderes locais ao reduzir a competência do Juiz de Paz e do Júri, além de elitizar este último.

A Lei $n^{\circ} 261$ consolidou o pacto intraelites imperiais mediante a centralização do poder político em nome do combate à anarquia política e da preservação da unidade nacional.

\section{A Reforma da Organização Judiciária (Lei no 2.033, de 20 de setembro de 1871): A Lei e a Conservação da Forma Monárquica de Governo.}

Sob a alegação de que a reforma judiciária suprimia poderes do Judiciário em favor do Executivo, dissidentes liberais arguiram, sem sucesso, sua inconstitucionalidade. Porém, assim como ocorreu com a Lei de Interpretação ao Ato Adicional, a verdade é que existia um sólido consenso liberal/conservador a respeito da necessidade da Lei $\mathrm{n}^{\circ}$ 261, de modo que a reforma subsistiu. Apenas com o advento da Lei $\mathrm{n}^{\circ} 2.033$, de 20 de setembro de 1871, regulamentada pelo Decreto $\mathrm{n}^{\circ} \mathbf{4 . 8 2 4}$, de 
10 de novembro de 1871, é que, por exemplo, a formação da culpa tornou-se novamente competência do Judiciário.

Tentativas anteriores à Lei ํo 2.033 visando à reforma do Judiciário não faltaram, mas não lograram êxito. Em 1854, por exemplo, Nabuco de Araújo, então Ministro da Justiça, propôs mudanças no sistema judiciário brasileiro, tendo enfrentado naquela oportunidade considerável resistência parlamentar que terminou por inviabilizá-las. Na realidade, tanto conservadores (saquaremas) como liberais (luzias) contribuíram para desfigurar o projeto reformista patrocinado por Nabuco de Araújo. Os primeiros temiam a politização do Poder Judiciário em detrimento de sua feição puramente técnica, o que justificaria, segundo eles, a permanência da magistratura subordinada ao Poder Moderador. Os magistrados deveriam continuar a se comportar como meros delegados do Governo Central e a sua atuação deveria permanecer ajustada aos desígnios deste último. Assim, por exemplo, na hipótese de conflito entre os seus direitos individuais e os interesses do Governo Central, o cidadão somente poderia protegê-los mediante a utilização das vias administrativas, sendo-Ihe vedado 0 acesso ao Judiciário com tal finalidade. No entendimento dos liberais, diferentemente, competiria ao Judiciário tutelar os direitos individuais, mesmo diante dos interesses do Estado. Em consequência, eles defendiam a reforma do Poder Judiciário com a finalidade de assegurar a autonomia das decisões judiciais, a estruturação da magistratura em carreira, o controle judicial sobre o processo eleitoral e o apartidarismo, além da separação entre as funções judiciais e policiais. Pretendiam, dessa maneira, que fosse feita uma reforma radical, o que, em última análise, conduziria à transformação da própria estrutura política do Estado brasileiro. Resumidamente, os liberais desejavam, basicamente, "constituir a autonomia de julgamento do Poder Judicial, cujos magistrados seriam independentes em relação ao governo e aos poderes locais, com uma carreira diferenciada e estruturada burocraticamente, e com poderes ampliados de intervenção sobre os conflitos sociais e sobre o processo eleitoral". ${ }^{16}$ Havia, portanto, diferentes concepções a respeito da organização judiciária brasileira que refletiam, por seu turno, pontos de vista

\footnotetext{
${ }^{16}$ Koerner, Andrei (1998). Judiciário e Cidadania na Constituição da República Brasileira, São Paulo: Hucitec, p.41.
} 
claramente contrastantes acerca da própria organização política nacional, das relações entre cidadão e Estado e da extensão e efetividade dos direitos e garantias individuais.

Tentativas ulteriores de reforma do Judiciário se sucederam. Em 1866, Nabuco de Araújo lutou uma vez mais, sem êxito, para viabilizar a efetiva independência judicial, a separação entre as funções policiais e judiciais e para restringir a extensão da prisão preventiva. Ele também propôs que fosse estendida a competência dos Juízes vitalícios de maneira a abranger todas as causas cíveis e criminais, sem exceção. Não obstante, a reforma do Judiciário somente veio a ocorrer com a entrada em vigor da Lei no 2.033, de 20 de setembro de 1871 por iniciativa de um gabinete liderado por liberais preocupados em conter a dissidência de tendência democratizante no interior do próprio partido. Sobre a reforma, Joaquim Nabuco assinalou posteriormente com grande dose de ceticismo que mais importante que a transformações legislativas então operadas na esfera judicial teria sido a mudança da cultura de nossos magistrados. Nabuco afirmava que "o que faltava para proteger e garantir a liberdade individual em nosso país era o interesse de cada um pela liberdade e o direito alheio". Em seu sentir, "onde o indivíduo não se interessa senão pelo que pessoalmente lhe concerne, a liberdade individual só pode ser protegida tornando-se ponto de honra de uma magistratura escolhida e superiormente educada, criando-se, por outra, uma aristocracia de juízes". ${ }^{17}$ Independentemente do acerto de tal afirmação, não há dúvida de que a concepção liberal acerca da autonomia do Judiciário em relação ao Poder Moderador contribuiu no longo prazo para estruturação burocrática deste Poder, o que certamente não teria desagradado Nabuco.

\section{Conclusão: A Organização Judiciária como Problema Político}

Todo e qualquer Estado adota uma política criminal no tocante à organização judiciária que reflete em maior ou menor medida a orientação política geral hegemônica e o exame da estrutura judiciária nacional imperial tão somente confirma esta tese. A política criminal relacionada à organização judiciária não é, de maneira alguma, neutra, mas politicamente orientada. Como é dado a perceber a partir da análise da organização judiciária imperial, toda e qualquer política criminal persegue determinados

\footnotetext{
${ }^{17}$ Nabuco, Joaquim (1997). Um Estadista do Império, Rio de Janeiro: Topbooks, p.640.
} 
fins, de maneira que reformas no sistema penal como um todo obedecem, sobretudo, a imperativos políticos mais gerais diante dos quais os aspectos propriamente técnicos se revestem de caráter secundário. O Estado Imperial, em particular, teve a sua fisionomia determinada em grande parte pelas regras de organização judiciária que contribuíram, por um lado, para eliminar a autonomia dos Governos Locais e, por outro, para preservar a unidade nacional, questão que até hoje constitui objeto de debate entre os historiadores brasileiros. A interdependência entre as esferas da política e do direito resta bem caracterizada quando observamos que as elites imperiais, fossem elas mais liberais ou mais conservadoras, valeram-se de reformas legislativas no plano da organização judiciária e do processo penal para lograr, consoante a conjuntura política, a descentralização ou a centralização do Estado brasileiro.

\section{Referências}

Coser, Ivo (2008). Visconde do Uruguai: Centralização e Federalismo no Brasil (18231866), Belo Horizonte: UFMG.

Ferreira, Gabriela Nunes (1999). Centralização e Descentralização no Império: 0 Debate entre Tavares Bastos e o Visconde de Uruguai, São Paulo: Editora 34.

Flory, Thomas (1986). El Juez y el Jurado en el Brasil Imperial, 1808 -1871: Control Social y Estabilidad Política en el Nuevo Estado, México: Fondo de Cultura Económica.

Holloway, Thomas H. (1997). Polícia no Rio de Janeiro: Repressão e Resistência numa Cidade do Século XIX, Rio de Janeiro: Fundação Getúlio Vargas.

Koerner, Andrei (1998). Judiciário e Cidadania na Constituição da República Brasileira, São Paulo: Hucitec.

Monteiro, Hamilton de Mattos (1990). "Da Independência à Vitória da Ordem". In Linhares, Maria Yedda (Org.) (1990). História do Brasil, Rio de Janeiro: Elsevier, p.129143.

Nabuco, Joaquim (1997). Um Estadista do Império, Rio de Janeiro: Topbooks.

Neves, Lúcia Maria Bastos Pereiras das; Machado, Humberto Fernandes (1999). O Império do Brasil, Rio de Janeiro: Nova Fronteira.

Prado Júnior, Caio (1999). Evolução Política do Brasil, São Paulo: Brasiliense.

Reis, João José; Silva, Eduardo (1989). Negociação e Conflito: A Resistência Negra no Brasil Escravista, São Paulo: Companhia das Letras. 
Slemian, Andrea (2008). "A nação independente, um novo ordenamento jurídico: a criação dos Códigos Criminal e do Processo Penal na primeira década do Império do Brasil". In Ribeiro, Gladys Sabina (Org.) (2008). Brasileiros e Cidadãos: modernidade política, São Paulo: Alameda, p.175-206. 